\title{
Biomarkers of Metabolic Syndrome in Serum of Some Cigarette Smokers in Delta State, Nigeria
}

\author{
I. Onyesom ${ }^{1}$, E. Osioma ${ }^{2, *}$, O. L. Testimi ${ }^{3}$, A. R. Rotu. ${ }^{3}$ \\ ${ }^{1}$ Department of Medical Biochemistry, Delta State University, Abraka, Nigeria \\ ${ }^{2}$ Department of Biochemistry, Faculty of Science, University of Ilorin, Nigeria \\ ${ }^{3}$ Department of Human Physiology (Biomedical Technology Option), Delta State University, Abraka, Nigeria
}

\begin{abstract}
Cigarette smoking could predispose an individual to a multitude of diseases which include metabolic syndrome. This study evaluates the biomarkers (blood glucose, body mass index [BMI], lipid profile and blood pressure) of metabolic syndrome in serum of some cigarette smokers in Delta State. One hundred apparently healthy male undergraduate students divided into two groups (50 smokers and 50 non-smokers) were recruited for the study conducted between August, 2010 and April 2011. Body mass index (BMI), blood glucose, blood pressure parameters and serum lipid profile were determined using standard procedures. Results indicate that smokers' systolic $(137.67 \pm 8.97 \mathrm{mmHg})$ and diastolic $(82.14 \pm 8.23 \mathrm{mmHg})$ blood pressure measures were significantly $(\mathrm{p}<0.05)$ elevated than those of the non-smokers (systolic: $129.93 \pm 10.33 \mathrm{mmHg}$, diastolic: $75.20 \pm 2.55 \mathrm{mmHg}$ ). Their body mass index (BMI) were comparable ( $\mathrm{p}>0.05$ ). Lipid profiling reveals that smokers' HDL-cholesterol level $(0.47 \pm 0.08 \mathrm{mmol} / \mathrm{L})$ was significantly lower than that of the non-smokers $(0.72 \pm 0.09 \mathrm{mmol} / \mathrm{L})$ but both groups expressed comparable LDL-Cholesterol levels, although smokers' level $(6.12 \pm 0.34 \mathrm{mmol} / \mathrm{L})$ is higher than the non-smokers' level $(6.10 \pm 0.42 \mathrm{mmol} / \mathrm{L})$. The ratio of HDL: LDL-cholesterol (an index of cardiovascular risk) is higher for non-smokers (0.12) compared with the smokers (0.08). Put together, results imply that smokers have higher risk of developing metabolic syndrome. Therefore, the existence and prevalence of metabolic syndrome among smokers in Delta State, Nigeria, should be investigated and documented for public campaign and formulation of policies that could reduce cigarette smoking.
\end{abstract}

Keywords Cigarette, Blood Pressure, Lipids, Body Mass Index

\section{Introduction}

Smoking is socially accepted in various communities including ours and legislations appear weak, hence the drastic increase in cigarette smoking around the world[1]. Cigarette smoking is a known risk factor for coronary artery disease (CAD), cancer and chronic obstructive pulmonary disease (COPD)[2]. Smoking is associated with several side effects and can predispose one to a multitude of diseases such as atherosclerosis and dyslipidaemia. Cigarette smoking may be a risk factor of metabolic syndrome. The syndrome is characterized by insulin resistance, glucose intolerance, hyperlipidaemia, increased body mass index (BMI), hypertension and atherosclerosis, but presence of any two is sufficient for clinical diagnosis and recognition of the syndrome.[3], reported that smoking causes more deaths from coronary heart diseases (CHD) and stroke than any other disease[4], observed that cigarette smoking is strongly associated with atherosclerosis.

* Corresponding author:

ejoviosioma@yahoo.com (E. Osioma)

Published online at http://journal.sapub.org/ajb

Copyright (C) 2012 Scientific \& Academic Publishing. All Rights Reserved
Cigarette smoking is a potent source of free radicals[5] and these radicals reduce the amount of reactive oxygen species (ROS) scavengers and induce oxidative damage. Free radicals also oxidize low density lipoprotein (LDL) cholesterol. Oxidized LDL-cholesterol increases the risk of atherosclerosis, one of the compliments of metabolic syndrome. Moderate and short term duration of cigarette smoking have been observed to change lipoprotein profiles [6] in a manner that may induce dysfunction and metabolic disorders [7].

Changes in lipid and lipoprotein levels among cigarette smokers in India[8-10] and in the UK[11] have been reported, but data regarding the biomarkers of metabolic syndrome among smokers in Nigeria are poorly documented. Therefore, this present study investigates the changes in biomarkers (BMI, glucose, lipid profile, blood pressure) of metabolic syndrome in serum of some randomly selected male smokers in Delta State, Nigeria.

\section{Materials and Methods}

Participants: One hundred apparently healthy male undergraduate students in the Delta State University, Abraka, Nigeria, were recruited for the study after obtaining their 
informed consent. The subjects were randomly divided into two groups ( 50 smokers and 50 non-smokers) and their ages ranged from 18-34 years. The smokers have been smoking for between 2-5years with a smoking rate of 2-5 sticks of cigarette per day. The smokers smoked all brands of cigarette found in their locality. The study was approved by the Research and Bioethics Committee of the Faculty of Basic Medical Sciences, Delta State University, Abraka, Nigeria. Participants (smokers and non-smokers) were matched in age, gender and body size, frame and habitus as judged by their similar BMI values.

Height Measurement: Height measurements were taken using a meter steel tape. The participants were made to stand erect, bare footed in underwear but without head tie or cap, against a wall and their heights were read to the nearest $0.1 \mathrm{~cm}$.

Weight Measurement: Weight of subjects was carried out using a bathroom weighing scale (Hana, China) and read to the nearest $0.1 \mathrm{~kg}$.

Body Mass Index (BMI) Determination: BMI was determined mathematically by dividing the weight obtained in $\mathrm{Kg}$ by the square of height measure in metres.

Measurement of Blood Pressure: Blood pressure was measured in a well-seated position after about $10 \mathrm{~min}$ of rest by a qualified medical practitioner using an electronic aneroid sphygmomanometer (SE 700; Seinex, England).

Collection of Blood Specimens: Five millimeters $(5 \mathrm{ml})$ of over-night fasting venous whole blood was collected from each volunteer using 21-gauge hypodermic disposable needle and syringe into a sterile, plain tube. The blood sample was allowed to clot, then dislodged and centrifuged at $1,200 \mathrm{xg}$ for $5 \mathrm{~min}$ at room temperature $\left(28-31^{\circ} \mathrm{C}\right)$ to obtain the serum which was decanted into bijou bottle and stored frozen until required for analysis. Biochemical analysis was done within $48 \mathrm{~h}$ of serum collection.

Biochemical analysis: Serum triglyceride was determined by enzymatic-colorimetric method[12]. Serum total cholesterol[13] and serum glucose[14] were determine spectrophotometrically. High-density lipoprotein cholesterol (HDL-cholesterol) was estimated using the method of [15], but low density lipoprotein cholesterol (LDL-cholesterol) was evaluated mathematically[16]. The commercial kits containing the reagents used were supplied by TECO Diagnostics, Anahein, CA 92807 USA.

Statistical Analysis: Student's' $t$-Test' was used to compare the calculated means of the parameters and the differences between mean values were considered significant at the 5\% probability level. All statistical calculations were performed using Version 16.0 of the SPSS-PC programme package.

\section{Results}

The results obtained from the investigation into changes in biomarkers of metabolic syndrome among male undergraduates in Delta State University, Abraka, Nigeria are shown (Table 1). Table 1 shows BMI, Serum glucose, lipid profile and blood pressure measures induced by cigarette smoking among male undergraduate students in Delta State University, Abraka, Nigeria.

Table 1. Cigarette smokers' and non-smokers' BMI, serum glucose, lipid profile and blood pressure measures, the biomarkers of metabolic syndrome

\begin{tabular}{ccc}
\hline Biomarkers & $\begin{array}{c}\text { Cigarette smok- } \\
\text { ers }(\mathrm{n}=50)\end{array}$ & $\begin{array}{c}\text { Non-cigarette } \\
\text { smokers }(\mathrm{n}=50)\end{array}$ \\
\hline $\begin{array}{c}\text { Body Mass Index, } \\
\text { BMI }\left(\mathrm{Kg} / \mathrm{m}^{2}\right)\end{array}$ & $20.38 \pm 2.25^{\mathrm{a}}$ & $20.42 \pm 2.69^{\mathrm{a}}$ \\
$\begin{array}{c}\text {-Serum glucose } \\
(\mathrm{mmol} / \mathrm{L})\end{array}$ & $3.10 \pm 0.37^{\mathrm{a}}$ & $3.49 \pm 0.39^{\mathrm{b}}$ \\
$\quad \begin{array}{c}\text { Triglycerides } \\
(\mathrm{mmol} / \mathrm{L})\end{array}$ & $0.011 \pm 0.003^{\mathrm{a}}$ & $0.012 \pm 0.002^{\mathrm{a}}$ \\
$\begin{array}{c}\text { Total Cholesterol } \\
(\mathrm{mmol} / \mathrm{L})\end{array}$ & $6.54 \pm 0.24^{\mathrm{a}}$ & $6.76 \pm 0.20^{\mathrm{b}}$ \\
$\begin{array}{c}\mathrm{HDL}-\text { Cholesterol } \\
(\mathrm{mmol} / \mathrm{L})\end{array}$ & $0.47 \pm 0.08^{\mathrm{a}}$ & $0.72 \pm 0.09^{\mathrm{b}}$ \\
$\begin{array}{c}\text { LDL-Cholesterol } \\
(\mathrm{mmol} / \mathrm{L})\end{array}$ & $6.12 \pm 0.34^{\mathrm{a}}$ & $6.10 \pm 0.42^{\mathrm{a}}$ \\
$\begin{array}{c}\text { HDL:LDL Cholesterol } \\
\text { ratio }\end{array}$ & 0.08 & 0.12 \\
$\begin{array}{c}\text { Systolic blood pres- } \\
\text { sure (mmHg) }\end{array}$ & $137.67 \pm 8.97$ & $129.93 \pm 10.33$ \\
$\begin{array}{c}\text { Diastolic blood pres- } \\
\text { sure (mmHg) }\end{array}$ & $82.14 \pm 8.23^{\mathrm{a}}$ & $75.20 \pm 2.55^{\mathrm{b}}$ \\
\hline
\end{tabular}

Values are expressed as mean $\pm \mathrm{SD}$, for ' $\mathrm{n}$ ' subject

Means not sharing a common superscript letter along a row differ significantly at $\mathrm{p}<0.05$

Results (Table 1) indicate that smokers and non-smokers have comparable $(p>0.05)$ BMI. Serum glucose concentration for non-smokers was significantly $(p<0.05)$ higher than that of the smokers. Systolic and diastolic blood pressure measures for smokers were significantly $(p<0.05)$ elevated compared with the non-smokers values.

Serum total cholesterol and HDL-cholesterol levels for smokers were significantly $(p<0.05)$ lower than those of the non-smokers. Both groups (smokers and non-smokers) had similar $(\mathrm{p}>0.05)$ triglyceride and LDL-cholesterol levels, although, the LDL-cholesterol level of smokers was higher than that of the non-smokers. HDL-cholesterol to LDLcholesterol ratio of the non-smokers was higher than that of the smokers. Reduced amounts of HDL-cholesterol, the lowered HDL: LDL-cholesterol ratio and the increased blood pressure measures, altogether represent a trend that indicates higher risk of metabolic syndrome among the smokers.

\section{Discussion}

Results of this study indicate that cigarette smoking did not adversely reduce body weight and BMI values were within the normal range $\left(20-25 \mathrm{~kg} / \mathrm{m}^{2}\right)[17]$. Fasting blood glucose for the non-smokers was significantly higher than that of the smokers. The effect of cigarette smoking on blood glucose remained contradictory. Our present observation agrees with[18] who reported hypoglycemia during smoking by 5 non- smokers and 6 smokers, but other workers saw comparable glucose levels between smokers and non- 
smokers[19,20], yet some group observed transient increase in plasma glucose concentration[21,22], suggesting an interplay of several influencing factors.

Nicotine increases plasma levels of norepinephrine and epinephrine which elevate hepatic glycolysis and gluconeogenesis leading to increase plasma glucose [23-26]. The hypoglycaemic effect of cigarette smoking observed in this present study could be due to poor feeding habits of most smokers in our locality, although, nutritional status was not assessed in this study.

The systolic and diastolic BP measures were significantly elevated among smokers as compared with non-smokers. This agrees with previous reports[27,28]. This could be the resultant effect of the increase in catecholamines by nicotine intake during smoking that is presided by an increase in heart rate and blood pressures $[23,24]$ and increase in aortic stiffness[27].

Smoking reduced plasma concentration of estrogen which leads to decreased HDL-cholesterol (anti-atherogenic fraction) level and increases insulin resistance causing hyperinsulinemia and thus elevating LDL due to decreased activity of lipoprotein lipase[29,30]. HDL to LDL ratio has been proven to be a reliable predictor of cardiovascular risk and is better than LDL-cholesterol or HDL-cholesterol alone[30]. The ratio can also be used to monitor the effectiveness of lipid-lowering therapies[31,32]. Results from this study indicate that HDL: LDL-cholesterol ratio was lower in smokers than in non-smokers.

Overall, the results present a pattern that reveals a higher risk of metabolic syndrome among smokers in Delta State, Nigeria. Therefore, the prevalence and mortality rates arising from metabolic syndrome among smokers need further investigation and documentation in order to compliment this baseline report and provide argument base data for the enforcement of legislation that could significantly reduce cigarette smoking in our society.

\section{REFERENCES}

[1] World Health Organization ((2003). Gender, Health and Tobacco. WHO, Geneva

[2] Meenakshisundervam, R., Rayendiran, C. and Thirumalaikolundusubramanian, P. (2010). Lipid and lipoprotein profiles among middle aged male smokers; a study from southern India. Tobacco Ind Dis 8:11

[3] Wald, N. J. and Hackshaw, A. K. (1996). Cigarette smoking; an epidemiological overview. Br Med Bull 52:3-11

[4] NjoIstad, I., Arnesan, E. and Lund-Larsen, P. G. (1996): Smoking, serum lipids, blood pressure and sex differences in myocardial infarction. A 12-year follow-up of the Finnmark study. Circulation 93:450-456

[5] Ross, R. (1986). The pathogenesis of atherosclerosis - an update. New Engl J Med. 314:488-499

[6] Raftopoulus, C. B.M. and Steinbeck, K. S. (1999). Co ronary heart disease risk factors in male adolescents with particular reference to smoking and blood lipids. J Adolesc Health 25(1):68-74

[7] Brischetto, C., Connor, W., Connor, S. and Matarazzo, J. (1983). Plasma lipid and lipoprotein profiles of cigarette smokers from randomly selected families; enhancement of hyperlipidemia and depression of high-density lipoprotein. Am J Cardiol 52:675-680

[8] Neki, N. S. (2002). Lipid profile in chronic smoker- A clinical study. JIACM 3:51-54

[9] Whig, J. Singh, C., Soni, G. and Bansal, A. (1992).Serum lipids and lipoprotein profiles of cigarette smokers and passive smokers. Indian J Med Res 96:282-287

[10] Venkatesan, A., Hemalatha, A., Bobby, Z., Selvaraj, N. and Sathiyapriya, V. (2006). Effect of smoking on lipid profile and lipid peroxidation in normal subjects. Indian J Physiol Pharmacol 50:273-278

[11] Craig, W., Palomaki, G. and Haddow, J. (1989). Cigarette smoking and serum lipid and lipoprotein concentration: an analysis of published data. BMJ 298:784-788

[12] Young, A. and Pestaner, D. L. (1975). Determination of triglyceride. Clin Chem 21:5-7

[13] Tarbutton, P. N. and Cunder, C. R. (1974). Enzymatic determination of total cholesterol in serum. Clin Chem 20:724

[14] Trinder, P. (1959). Determination of blood glucose using 4-amino antipyrine. J Clin Path 22:246

[15] Tietz, N. W. (1986). Clinical Guide to Laboratory Tests. W. B. Saunders Co; Philadelphia

[16] Friedewald, W. F., Levy, R. I. and Fredrickson, D. S. (1972). Estimation of the concentration of low-density lipoprotein cholesterol in plasma without use of the preparative ultracentrifuge. Clin Chem 18(6):499-502

[17] Williams, S. R. (1990). Essentials of Nutrition and Diet therapy. Times Mirror and Moshy College Publishing, Missioniri

[18] Ssalischtscheff, A.S. (1930). Uber de Einfluss des Nicotins und der stoffe des Tabakrauches auf den Blutzuckerspiegel. Ztschr. Ges. Exper. Med 74:14

[19] Ko, G. T.C., Chan, J.C.N., Tsang, L.W.W., Critchley, J.A.J.H. and Cockram, C. S. (2001). Smoking and diabetes in Chinese men. Postgrad Med J 77:240-243

[20] Ahmed, S. T. and Memon, M. A. (2008). Smoking and fits relationship with blood pressure, blood glucose, and blood parameters in patients with coronary heart disease. Pak J Physiol 4(1): 5-7

[21] Houston, T. K., Person, S.D.M., Pletcher, M. J., Liu, K., Iribarren, C. and Kiefe, C. I. (2006). Active and passive smoking and development of glucose in tolerance among young adults in a prospective cohort; CARDIA Study. BMI 332:1064-1069

[22] Nakanishi, N., Nakamma, K., Matsuo, Y., Suzuki, K. and Tatara, K. (2000). Cigarette smoking and risk for impaired fasting glucose and type 2 diabetes in middle-aged Japanese men. Ann Intern Med 133:183-191

[23] Ball, K., and Turner, R (1974). Smoking and heart. The basis 
for action. Lancet 2:822-826

[24] Hill, P. and Wynder, E.L. (1974). Smoking and cardiovascular disease: Effect of nicotine on the serum epinephrine and corticoids. Am Heart J 87:491-496

[25] Porte, D., Graber, A. L., Kuzuya, T. and Williams, R.H. (1966). The effect of epinephrine on immunoreactive insulin levels in man. J Clin Invest 45:228-236

[26] Steinberg, D., Nestel, P.J., Buskirk, E.R. and Thompson, R.H.( 1964). Calorigenic effect of norepinephrine correlated with plasma free fatty acid turnover and oxidation. J Clin Invest 43:167-176

[27] Rhee, M. Y., Na, SH, Kim, Y. K. and Lee, M.M. (2007). Acute effects of cigarette smoking on arterial stiffness and blood pressure in male smokers with hypertension. Am J Hypertens 20(6):637-641

[28] Kim, J. W., Park, G.G., Hong, S. J., Park, S. M. and Rha, S. W. (2005). Acute and chronic effects of Cigarette smoking on arterial stiffness. Blood pressure 14(2):80-85
[29] HL, B. (1988). Pharmacologic aspects of cigarette smoking and nicotine addiction. New Engl J Med 319:1318-1330

[30] Reaven, G. M. (1988). Role of insulin resistance in human disease. Diabetes 37(12): 1595-1607

[31] Manninen, V., Tenkanen, L., Koskinen, P., Huttunen, J.K., Manttari, M., Heinonen, O.P. and Frick, M.H. (1992). Joint effects of serum triglyceride and LDL-Cholesterol and HDLCholesterol concentrations on coronary heart disease risk in the Helsinki Heart Study. Implication for treatment. Circulation $85: 37-45$

[32] Kannel, W.B.(2005). Risk stratification of dyslipedemia: Insights from the Framingham study. Curr Med Chem Cardiovasc Hematol Agents. 3:187-193

[33] Cullen,P., Schulte, H. and Assmann, G.(1997). The Munster Heart Study(PRO-CAM) Total Mortality in Middle Aged Men is increaser at low total and LDL cholesterol concentrations in smokers but not in non smokers. Circulation 96:2128-2136 